\title{
NOTES ON THE VALUE OF SPRING RYE FOR CULTIVATION
}

\author{
K. MultamäKI
}

Agricultural Research Centre, Department of Plant Breeding, Jokioinen

Received June 27, 1961

The cultivation of spring rye is only of minor importance in Finland. Thus, according to the agricultural statistics from the year 1956 (3), the growing area of this crop comprised 1103 ha or $0.04 \%$ of the total arable area. The corresponding area of winter rye was, at the same time, 82954 ha $(3.22 \%)$.

Spring rye is chiefly cultivated on poor soils (2). Almost without exception, unimproved land varieties are used. The average yield of spring rye per hectare in 1956 was estimated at $1113 \mathrm{~kg}$, that of winter rye at $1403 \mathrm{~kg}(3)$.

About the middle of the 1930's, the breeding of spring rye was incorporated to the working programme of the Department of Plant Breeding at Jokioinen. This work was taken over by professor Vilho A. Pesola at the time the director of the Department who was, in addition, in charge of the breeding of, inter alia, winter rye.

The breeding of spring rye at Jokioinen was conducted only on a relatively small scale. This work aimed, in the first place, at a better productivity and at more profitable kernel properties. Improving the stiffness of the straw was also considered important.

At the initiative of professor Pesola crosses were made, among others, between spring and winter rye in order to transfer some of the valuable properties of the latter varieties to the progeny. Family-groups from different crosses were grown on isolation plots in the experimental field area of the Department. In the breeding work the typical mass-selection method was applied.

One of the spring rye varieties developed in the way described above soon aroused attention in field tests by its profitable characteristics. This variety originated in the cross between a native spring rye strain received from East Finland, and the Toivo winter rye bred at the Department. Before long, all spring rye breeding material except this variety was discarded. Systematic field tests of this variety, under the name Jokioinen spring rye, were started in 1944 at the Department. At present the variety is being cultivated for increase of seed as well.

The soil of the experimental field at Jokioinen is heavy clay which is fairly common in Southwest Finland. The state of cultivation of the experimental field 
may be considered medium or good. Variety testing of the Jokioinen spring rye has been carried out in the years $1944-60$ in the comparative yield trials of spring wheat with the Swedish Diamant (Diamond) as the standard variety.

As regards the weather conditions in the years $1944-60$ at Jokioinen and their effect on the growth of spring rye, only a brief survey is presented in this connection. The conditions of temperature and precipitation were very favourable for the growth of spring rye in the summers of 1948, 1952 and 1953; in these years the yields of spring rye were exceptionally high. The growing seasons in 1950,1956 and 1960 were also fairly advantageous in this respect. In the years 1946, 1954, 1955 and 1959, however, the yields of spring rye remained rather poor due to drought that greatly hampered the growth of the crop. In rainy harvest periods, on the other hand, sprouting in ear and ergot formation lowered the quality of the yield of spring rye.

No pest injury has been observed on spring rye during the period reported. In some years yellow rust (Puccinia glumarum) occurred in plant stands causing, however, only slight damage.

In the present report on the properties of the Jokioinen spring rye are given the average yields etc. of this variety from the years $1944-60$ at Jokioinen (Table 1). In order to demonstrate more closely the cultivation value of spring rye, these results are compared with corresponding data of the standard variety of the trials, the Diamant spring wheat. In addition to this, comparisons were carried out also with the experimental data of the standard of winter rye, the Toivo variety. The statistical treatment of the experimental results as well as the marking of confidence limits with asterisks were accomplished in accordance with BONNIER and TEDIN (1).

In examining the various features of the improved strains it appears from Table 1 that spring rye and spring wheat emerged particularly well and were equal in this respect. The variation in emergence capacity proved to be fairly small in both spring cereals investigated. Somewhat more variation was observed in the number of days between the dates of sowing and of coming into ear of these two cereals. Thus, the length of this period in the Jokioinen spring rye varied from 38 days in 1960 to 65 days in 1945, the corresponding times for the Diamant spring wheat being 46 days in 1960 and 65 days in 1952. On an average, the Jokioinen spring rye came into ear 7 days earlier than the Diamant spring wheat. The development of spring rye from this stage to maturity, however, required very little more time than that of spring wheat. Thus, the difference in the total growing time between these cereals amounted only to 3 days. The length of the growing time varied from 91 days in 1947 to 125 days in 1952 for the Jokioinen spring rye, and from 91 days in 1947 to 130 days in 1952 for the Diamant variety.

In comparisons of the five other characteristics it is possible also to consider the properties of the Toivo winter rye. As regards the straw qualities, the Jokioinen spring rye holds an intermediate position between the other two cereals (Table 1). Spring wheat proved to have the shortest straw, that of spring rye was distinctly longer, the straw of the winter rye being the longest. The notes on the strength of straw showed considerable variation. Anyhow, spring rye proved to be significantly weaker in straw than spring wheat while, on the other hand, it was considerably more resistant to lodging than winter rye. 


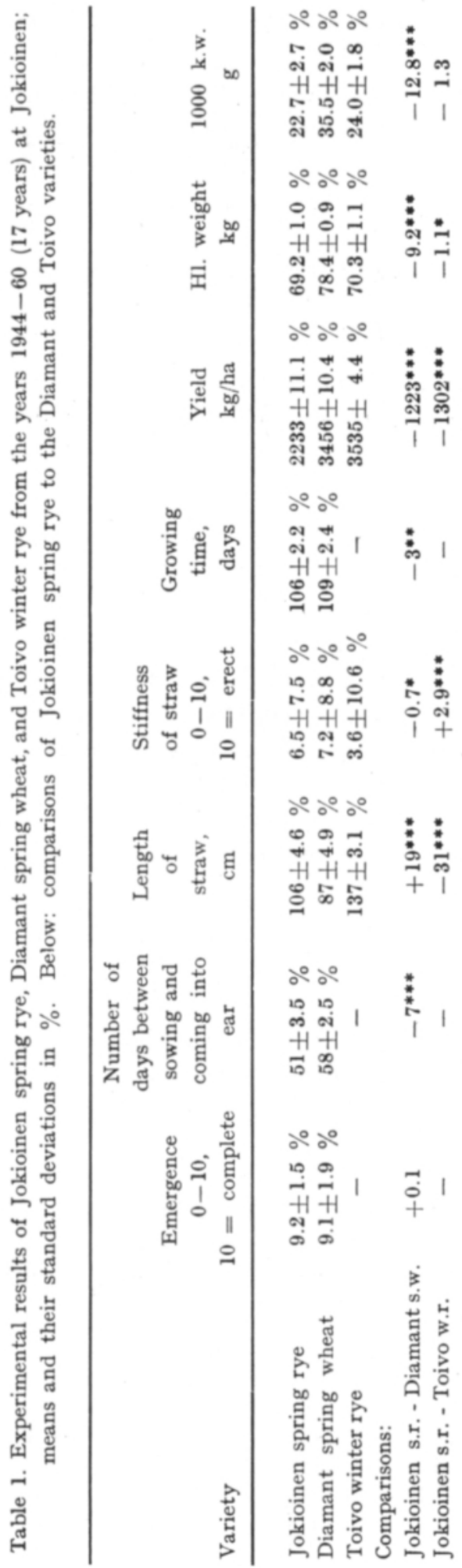


The most interesting property of spring rye, from the practical point of view, obviously is the productivity of this crop. As is evident from Table 1, the yields of both spring rye and spring wheat varied considerably in the trials in $1944-60$. The lowest yield, $1030 \mathrm{~kg} / \mathrm{ha}$, of the Jokioinen spring rye was obtained in 1954; the highest yield, $4804 \mathrm{~kg} / \mathrm{ha}$, was harvested in 1952. The corresponding yields for the Diamant spring wheat were $1566 \mathrm{~kg} /$ ha in 1954 and $5652 \mathrm{~kg} / \mathrm{ha}$ in 1952 . The yields of the Toivo winter rye varied less than those of spring rye and spring wheat, from $2062 \mathrm{~kg} / \mathrm{ha}$ in 1956 to $4444 \mathrm{~kg} / \mathrm{ha}$ in 1953 . The average yielding capacity of spring rye proved to be distinctly less than that of the other two cereals, only $64.6 \%$ of that of spring wheat and $63.2 \%$ of that of winter rye.

The hectolitre weight of spring rye was slightly less than that of winter rye. (Table 1). Further, no significant difference was noted between the kernel sizes of spring and winter rye.

\section{$S u m m$ ary}

Spring rye proved to be slightly earlier than spring wheat. The straw of spring rye was longer and weaker than that of spring wheat, on the other hand it was shorter and stiffer than that of winter rye. The yielding capacity of spring rye was only about $2 / 3$ of that of both spring wheat and winter rye. The kernel properties of spring and winter rye proved about equal.

Because of its low yielding capacity spring rye can not be recommended for cultivation on productive soils in South Finland.

R E F E R N C E S

(1) Bonnier, G. \& Tedin, O. 1940. Biologisk variationsanalys. 325 p. Stockholm.

(2) SAuli, J. O. 1932. Kasvituotanto: 639-640. Porvoo.

(3) Suomen tilastollinen vuosikirja 1957: Maatalous.

S E L O T U S :

HAVAINTOJA KEVÄTRUKIIN VILJELYARVOSTA

K. MUltamäKI

Maatalouden tutkimuskeskus, Kasvinjalostuslaitos, Jokioinen

Tutkimuksen tarkoituksena on ollut valaista suomalaisen kevätrukiin viljelyarvoa. Tässä mielessä on tarkasteltu Maatalouden tutkimuskeskuksen kasvinjalostuslaitoksella kehitetyn Jokioisten kevätrukiin koetulosaineistoa. Tätä itäsuomalainen maatiaiskevätruis $\times$ Toivo-syysruis-risteytyksestä polveutuvaa jalostetta on kokeiltu kevätvehnän valmistavassa kokeessa Jokioisissa vuosina 1944-60 eli 17 vuoden aikana. 
Jokioisten kevätruiskokeilusta saadut keskiarvotulokset on esitetty taulukossa 1, jossa on vastaavat koetulokset myös kevătvehnän mittarilajikkeesta Timantista sekä koetuloksia syysrukiin verranteesta Toivo-rukiista. Jokioisten kevätruista on verrattu erikseen näihin kumpaankin jalosteeseen.

Jokioisten kevätruis alkoi tähkiä 7 päivää aikaisemmin kuin Timantti-kevätvehnä, mutta kehittyi tämän jälkeen suhteellisesti hitaammin kuin viimeksi mainittu lajike. Kevätrukiin kasvuaika oli 3 päivää lyhyempi kuin kevätvehnän.

Kevätrukiin olki oli pitempi ja heikompi kuin kevätvehnän, mutta lyhyempi ja lujempi kuin syysrukiin.

Kevätrukiin ja kevätvehnän sadot muuntelivat koevuosien aikana enemmän kuin syysrukiin. Kevätrukiin sato oli keskimäärin vain $64.6 \%$ kevätvehnän ja $63.2 \%$ syysrukiin sadosta. Kevät- ja syysrukiin jyvän ominaisuudet olivat suunnilleen samanlaiset.

Niukkasatoisuutensa vuoksi ei kevätruista voida suositella viljeltäväksi hyväkuntoisilla mailla Etelä-Suomessa. 